\title{
The Implementation of Cooperative Integrated Reading and Composition Strategy to Improve the Students' Ability in Reading Comprehension
}

\author{
Dina Rahma Br Ginting \\ English Applied Linguistics \\ Universitas Negeri Medan \\ Medan, Indonesia \\ Dinarahma25@gmail.com
}

\begin{abstract}
Cooperative integrated reading and composition (CIRC) is a comprehensive approach to instruction in reading and composition/language arts. Thus, this research is aimed to find out the implementation of CIRC strategy in improving the students' ability in reading comprehension. In constructing this research, the researcher used classroom action research method. The qualitative data was taken from observation sheet, interview and diary notes and the quantitative data was taken from test. The result of data analysis showed that there was an improvement on the students' ability in comprehending text it can be seen from the students' score in pre-test who got up to 79 there were only 2 of 41 students, and the percentage of the students' score in post-test I who got up to 79 were 10 of 41 students or it's about $19.5 \%$. Then the finding showed that the total improvement of the students' score from the pre-test until post-test II is $51.2 \%$. In another words, the students' ability were become better in the first meeting until the last meeting. It indicated that the implementation of CIRC strategy can improve the students' ability in reading comprehension and the teaching learning can be effective.
\end{abstract}

Keywords: students' ability, reading comprehension, CIRC strategy.

\section{INTRODUCTION}

Learning is an activity of mental/psychic in an active interaction with environment, which produces a number of changes in the knowledge, understanding, skill, attitudes and value. Change is relatively constant and traces [1]. Learning is action and complex students' behavior. Thus, learning is an activity that can result in changes in behavior, potential or actual. Learning English has many skills that students should be able to comprehend, such as speaking, listening, writing and reading.

Reading is a way to get information from something that was written. Reading is thinking, understanding and getting at the meaning behind text, which is a good thing for language students. It requires students' mind as a part of the process of language acquisition, thus the students must be able to get the meaning behind the text especially to comprehend the text well.
Reading is an essential skill for all students at all levels. Reading is the ability to draw meaning from the printed page and interpret the information approximately [2]. By reading, students are expected to get the knowledge and to understand the context from that has been explained in the text. But, nowadays, the fact is the students do not know the essential of reading itself. They just read the text such as from textbooks, newspaper, magazines without getting the meaning. Reading is a very complex skill and for this reason it is not surprising to find that some children encounter difficulties in learning to read [3]. To help them do this they need to be taught a range of reading comprehension strategies and be encouraged to reflect on their own understanding and learning. To understand reading comprehension well is influenced by many factors, such as: mastering tense, sentence pattern, vocabulary, method and strategy etc. Strategy is a way that the teacher used in teaching learning process.

CIRC is a comprehensive strategy for teaching reading, writing and language arts. CIRC consists of three principles elements: story related activities, direct instruction in reading comprehension and integrated language arts and writing. CIRC consists of three principles elements: story related activities, direct instruction in reading comprehension and integrated language arts and writing [4]. CIRC is considered to be most effective way of teaching reading comprehension in order to improve the students' ability in reading comprehension. The implementation of cooperative integrated reading and composition method was effective as it could increase students' ability in reading comprehending recount text [5] [6]. Ideally, if the teacher used various strategies in teaching, so the students' ability will be increased too especially in reading comprehension. But in fact, based on the writer observation, it found that most of the students still have low ability in reading comprehension. It can be seen by the mistakes that they made, when they were asked to read they are only read without comprehend the text and their score in reading comprehension was so low. Thus, this study would like to explore the students' ability in reading comprehension and to find out the students' ability at reading comprehension after implementing CIRC strategy. 


\section{THEORETICAL REVIEW}

\section{Definition of Ability}

Ability is a skill or an individual person's potential to master the skill of doing various tasks in a job or an assessment of a person's actions. Ability to understand and use language has a high positive relationship with mental capacity and readiness to read. If mental capacity is high, language ability usually will also be high, if it is low, language development is likely to be retarded. As an integral part of total language development, reading is limited by any factor that reduces ability to communicate [7].

It is unrealistic to expect pupil to recognize, understand and interpret printed words if that pupil is not familiar with their oral counterparts. Thus, the ability to understand and use oral language provides the background for reading comprehension. It is assumed that if reading is taught properly, a pupil should be able to read at the approximate level on which he or she speaks and understands .

\section{Reading}

Reading is thinking process. It is the act recognizing which requires interpretation of graphic symbol. Reading can be taught as a way to draw information from the text and to found an interpretation of that information. The process of drawing information and interpreting information requires the work of the brain actively [2].

There are two types of reading classroom performance. They are oral and silent reading. At the beginning and intermediate levels, oral reading can be served as an evaluate check on bottom-up processing skills, double as a pronunciation check and serve to add some extra students' participation. Meanwhile silent reading may be subcategorized intensive and extensive reading [8].

Intensive reading is usually a classroom oriented activity in which students' attention to grammatical forms, discourse markers and other surface details for the purpose of understanding literal meaning, implication and rhetorical relationship. Sometimes, intensive reading is defined as reading carefully for an extract understanding or text.

Extensive reading is reading for pleasure with emphasis on general understanding. It carried out to achieve a general understanding of a usually somewhat longer text such as book, long article or essay etc, most extensive reading is performed outside of class time.

Of course there are not just two contrasting ways of reading but an infinite variety of strategies which are interrelated and overlapping. Intensive and extensive reading is complementary and both are necessary, as well as other approaches which perhaps fit into neither category.

\section{Cooperative Integrated Reading and Composition (CIRC) Strategy}

Cooperative learning teaching is one model of learning that support contextual learning. Cooperative learning teaching system can be defined as a system of work/study in a structure group. Cooperative learning is teaching and learning strategies that emphasize the attitude or behavior in work or assist in co-operation between each other in a regular structure in the group, consisting of two or more people.

Cooperative integrated reading and composition can be defined as a learning approach in which small, mixed student groups form both in the class and out of class environments to ensure students help each other in learning an academic subject in the scope of a common goal, where their self esteem increases and their communication, problem solving and critical thinking skills develop and where they actively participate in the teaching process 7 .

Cooperative integrated reading and composition is a comprehensive approach to instruction in reading and composition/language arts. In CIRC reading, students are taught in reading groups and then return to mixed ability teams to work on a series of cognitively engaging activities, including partner reading, making predictions, identification of characters, settings, problem and problem solution, summarization, vocabulary, reading comprehension exercises, and story related writing.

The major components of CIRC are as follows [4]:

1. Reading Groups

Students are assigned into two reading groups according to their reading level. The level based on the score they get in the pre test. Then, the teacher gives instruction to the whole class. In this procedure, teacher needs to ensure students that it is no problem whenever they are.

\section{Teams}

Team is often into background building activities. The teams are divided into several teams from the different level ability in reading. For example a team consists of two students from high reading group and two students from low reading group.

\section{Story-Related Activities}

Story is introduced and discussed in teacher led reading groups that meet an approximately twenty minutes each meeting. In these groups, the teacher sets a purpose for reading, introduce new vocabulary, review old vocabulary and discuss the text after students have read it. After the story is introduced, the students will do a series of activities for them to do in their teams. The sequence of activities is as follows:

\section{- Partner Reading.}

Students read the story aloud with their partner, alternating each paragraph. The listener corrects any errors the reader may make. The teacher assesses student performance by circulating and listening in as students read to each other

For example, the reading text consists of four paragraphs. Then in pairs each students reads two paragraphs. Students who act as listener may correct any error of his partner may make. The teacher assesses student performance by circulating and listening in as students read to each other. If the teacher hears the error of students in reading the text, she can directly corrects the error. After the students finish their partner reading then the teacher reads the text again for the students.

- Story Grammar and Story Related Writing.

Students are given questions related to the text that emphasize the text grammar-the structure that underlies all the content of the text. They are instructed to identify the 
problem and the solution of the problem, the setting and etc. Then, the teacher give student an explanation about the grammar features in the text. For examples, the use of simple past tense in the text, the use of regular and irregular verbs in the past form. At the end, students respond to the text as a whole and write a few paragraphs.

\section{- Words Out Loud}

Students are given a list of vocabulary used in the text, they should learn to read these words correctly in any order without hesitating or stumbling. Students practice these word lists with their partner or other teammates.

\section{- Word Meaning}

After students practice their pronunciation of the words in the list of vocabulary, they are asked to look for the meaning of the words. They are allowed to look up the meaning in the dictionary. Then, they are asked to write a sentence of one word that include in the list. Of course teacher firsts give an instruction in making a simple sentence to the students.

4. Tests

At the end of three class periods, students are given a comprehension test on the text, asked to write meaningful sentences for each vocabulary word, and asked to read the word list aloud to the teacher. Students are not permitted to help one another on this test.

5. Direct Instruction in Reading Comprehension

Students receive direct instruction in specific reading comprehension skills, such as identifying main ideas, understanding causal relations and making inferences. As teacher explains the instructions then teacher assesses the students by giving them the task.

6. Integrated Language Arts and Writing

On all writing assignments, students draft composition after consulting teammates and the teacher about their ideas and organizational plans, work with teammates to revise the connect of their composition and emphasizing the form of grammatical and mechanical correctness.

\section{The Advantages and Disadvantages of CIRC}

The advantages of this strategy:

- CIRC can improve students' participation to share ideas in classroom and solve the problem about the text.

- CIRC can dig the prior knowledge of students to get the new fact or ability and guide the students to think actively.

- Helping students that has low ability in reading

- The students are able $t$ understand the questions and check their work.

- Trained to be able to cooperate and respect the opinion of others.

- Reduced the dominance of teacher in the learning

- Improve learning outcomes

The weakness of this strategy:

This strategy can be only implemented in language lesson aspect. It can't use to teach others subject, such as: math, chemistry, physic. In presenting section often less effective because it takes a long time.

\section{METHOD OF RESEARCH}

In this study, the writer used classroom action research (CAR) method. Action research is one of the types of investigation that is characteristic reflective participative, collaborative and spiral which has the purpose to repair and increase the system, method, process, competence and situation of teaching learning [9]. Classroom action research as the systematic approach to investigation that enables people to find effective solution to problem they confront in their everyday life [10]. The data for this study was the contribution of quantitative and qualitative. The qualitative data were taken from interview and observation sheet. The quantitative data were taken from the mean of students score in taking test. The subject of research was all of the students VIII in academic year 2014/2015 at Junior High School (Madrasah Tsanawiyah Negeri 2) Medan. Population was the most significant factor in conducting a research. Population was all cases, situations or individuals who share one or more characteristic. Population was overall subject of research. Population was a region consisting of generalization; objects or subjects who have certain qualities and characteristic that set by the researcher to learn and then draw conclusion. The population was the group of interest to the researcher, the group to which she or he would like the result of the study to be generalized. The population of this study was the eight year students of Junior High School Medan. The VIII grade students divided into 10 classes.

Sample is part of population which is supposed to represent the characteristic of the population. Therefore, sample would take from part population, but not whole. The part of population is observed is called a sample. Sample is a group of individual which is taken from a given population. The writer chose the one class as sample. The writer chose the samples based on the consideration that the class has a little different score in English achievement. The sample of this research was the students of eighth grade, exactly VIII-6 class. This research was conducted in one class which consisted of 41 students.

\section{Technique of Collecting Data}

There were some technique of collecting the data, they were:

1. Test. In this case, the students would test by asking them to answer 20 items of questions, which were related to the text that they will read. On the pre-test the students will be instructed to read text and answer the question, while on the post test the research would instruct them to read text and answer the question after implementing the cooperative integrated reading and composition strategy.

2. Observation sheet. This instrument would use to investigate the situation and the problems find during the teaching and learning process. It would useful to know the students' reaction and to see the development 
existing when applying CIRC strategy in the classroom.

3. Interview. The researcher would ask a set of oral question to the teacher or the students who could give information to complete the data.

4. Diary notes, which would use to note personal evaluation about the situation of the class while teaching learning process related to progression improvement. The researcher would write all important events during the research would be conducted on diary notes.

\section{Technique of Analyzing Data}

This study would apply quantitative and qualitative data. Wallace states that the quantitative data is broadly used to describe what can be measured or counted and can therefore be considered objective while the qualitative data is used to describe data which are able to being counted or measured in an objective way, and therefore subjective. The quantitative data were found by analyzing the test result of the students and the qualitative data were found by describing the situation during the teaching learning process [11].

The qualitative data would analyze from observation sheet, diary notes and interview while the quantitative data would analyze by computing the score of reading test.

\section{RESULT AND DISCUSSION}

The observation activities was conducted by the English teacher of eight grade and the result in the first cycle showed that the students were still confused of how to apply CIRC strategy because the researcher did not explained it clearly thus the students were confused when doing their task, some of students made noise during the teaching learning process that disturbed the learning process. Furthermore, in cycle two it was found that the implementation of CIRC strategy was running well. CIRC strategy created a good environment in teaching and learning recount text in which the students became active and participated in the class. They gave their attention to the teacher's explanation and instruction. They gave good response to the activities in the classroom. Their communication, problem solving and critical thinking skills develop and where they actively participate in the teaching process [12]. Then, from the interviewed, it could be concluded that the implementation of CIRC strategy was suitable and enjoyable strategy to improve the students' ability in reading comprehension.

\section{Quantitative Data}

Table1.1. The percentage of the implementation of cooperative integrated reading and composition strategy to improve the students' ability in reading comprehension

\begin{tabular}{|c|c|c|c|}
\hline \multicolumn{2}{|c|}{ Meeting } & $\begin{array}{c}\text { The students } \\
\text { who got up to 79 }\end{array}$ & Percentage \\
\hline Cycle I & Pre-test & 2 & $4.90 \%$ \\
& Post-test I & 10 & $24.40 \%$ \\
\hline $\begin{array}{c}\text { Cycle } \\
\text { II }\end{array}$ & Post-test II & 23 & $56.10 \%$ \\
\hline
\end{tabular}

Based on the table above, the result showed the improvement of the students' score from the pre-test to post-test. In the pretest of the first cycle, students who got up to 79 there were only 2 of 31 students $(4.90 \%)$. In the post-test of the first cycle, students got up to 79 there were only 10 of 41 students $(24.40 \%)$. Then, in the post-test of the second cycle, students who got up to 79 there were 23 of 41 students $(56.10 \%)$. It was indicated that there was an improvement on the students' ability in reading comprehension by implementing CIRC strategy. It was supported by the fact that the students' score was improved in every cycle.

In the other words, the students' ability in reading comprehension improved in the first meeting to the next meeting. Besides that, the students' ability in reading comprehension can be described from qualitative data. They are:

\section{Observation Sheet}

The observation activities conducted by the teacher of class VIII-6 and the result in the first cycle showed that the students were still confused of how to apply CIRC strategy because the researcher did not explained it clearly thus the students were confused when doing their task, some of students made noise during the teaching learning process that disturbed the learning process.

Furthermore, in cycle two it was found that the implementation of CIRC strategy was running well. The atmosphere of the teaching learning process was comfort, lively, and enjoyable. CIRC strategy created a good environment in teaching and learning recount text in which the students became active and participated in the class. They gave their attention to the teacher's explanation and instruction. They also asked question about what they did not understand well while the teacher explaining the material. They gave good response to the activities in the classroom.

\section{Interview}

The interview was conducted in two sessions. The first session was conducted in the first meeting and the second session was conducted in the last meeting after conducting cycle II. In the first session, the students were interview about their opinion in learning English and the strategy that the English teacher used to teach them. They were asked about the strategy that they would like in learning English, especially reading comprehension. Then, the researcher also interviewed the English teacher about the students' ability in reading comprehension and the strategy that she used to apply in teaching reading text.

In the second session, the students were interviewed to get their comment or opinion on the implementation of cooperative integrated reading and composition strategy. And the English teacher of that class was also interviewed about the same question. From the interviewed, it could be concluded that the implementation of CIRC strategy was suitable and enjoyable strategy to improve the students' ability in reading comprehension.

\section{Diary Note}

From the diary notes, it was found that at the beginning of the meeting most of the students were still not interested to 
read recount text and although they read the text, they did not understand what they had read. But, after the researcher applied cooperative integrated reading and composition strategy, the students became enthusiastic to learn and to read the recount text. They worked both in their group and individually. Therefore in every test administered after applying CIRC strategy, they could answer the questions given by the researcher well. The students' score kept improving from the pre-test to the post-test cycle II.

\section{CONCLUSION}

Students' ability at reading comprehension before implementing CIRC strategy was very low. They still had lack of vocabulary, they didn't know about the generic structure of the text, and they could not find the main idea of text. Because of that, the students didn't interest in learning English, they felt bored in comprehending text especially recount text. But, there is a significant improvement at the students' ability after implementing CIRC strategy. It was proved that the students' ability at reading comprehension always improve in every cycle because the analysis of quantitative data has shown that the score of the students was improved from the first to the last test. Then, the qualitative data from the observation sheet and interview indicated that the students was also felt more fun to study English, they had interest in reading comprehension and actively during the teaching learning process and most of the them became more active working in the group. It was strengthened by the improvement of theirs' reading scores. Therefore, CIRC strategy significantly improves the students' ability in reading comprehension.

\section{REFERENCES}

[1] Winkel, W. S, Learning Activities, New York: Pearson Education, 2007, pp. 59.

[2] Grabe, William and Stoler, L Fredricka, Teaching and researching reading, England: Person Education, 2002, pp.4-29.

[3] Westwod, Peter, Reading and learning difficulties. Australia: Acerpress, 2001, pp. 25

[4] Slavin, Robert E, Cooperative learning (theory, research and practice), Englewood Cliffs, New Jersey: Prentice Hall, 1995, pp.2-106.

[5] Izar, Julisah, Improving student's ability in comprehending recount text through cooperative integrated reading and composition method at eight grade of MTs Al-Hasanah Medan, 2014. (Unpublished)

[6] Indriany, Florida Barus, Improving students' reading achievement in narrative text through cooperative integrated reading and composition technique, 2011.(Unpublished)

[7] Kennedy, Methods in teaching developmental reading $2^{\text {nd }}$ Edition, West Virginia University: F.E. Peacock Publisher, 1977.

[8] Brown, Douglas H, Teaching by principles: an interactive approach to language pedagogy $2^{\text {nd }}$ Ed, New Jersey: Logman, 2001, pp.300-312.

[9] Arikunto, Suharsimi, prosedur penelitian suatu pendekatan praktik, Jakarta: PT Asdi Mahasatya, 2006, pp. 5-99

[10] Stringer, Earnest T, Action research third edition, London: Sage, 2007, pp. 1.

[11] Wallace, Michael J, Action research for language teachers, Cambridge: Cambridge Univeristy Press, 1998, pp. 3.

[12] Hannesey D, Evans R, Small group learning in the community collage classroom, The Community College Enterprise, 2006, pp. 8. 